\title{
Adapting the Balanced Scorecard into the HealthCare Industry: A Literature Review, New Insight and Future Directions
}

\author{
Kim-Fatt Khiew', Ming-Chih Chen1, Ben-Chang Shia², Chun-Hen Pan ${ }^{3}$ \\ ${ }^{1}$ Graduate School of Business Administration, Fu Jen Catholic University, New Taipei City, Taiwan \\ ${ }^{2}$ School of Health Care Administration, Taipei Medical University, Taipei, Taiwan \\ ${ }^{3}$ Alison Maternal and Child Clinic, New Taipei City, Taiwan \\ Email: jimmykhiew@gmail.com
}

How to cite this paper: Khiew, K.-F., Chen, M.-C., Shia, B.-C. and Pan, C.-H. (2017) Adapting the Balanced Scorecard into the HealthCare Industry: A Literature Review, New Insight and Future Directions. Open Journal of Business and Management, $\mathbf{5}$, 611-623.

https://doi.org/10.4236/ojbm.2017.54052

Received: July 28, 2017

Accepted: August 21, 2017

Published: August 24, 2017

Copyright $\odot 2017$ by authors and Scientific Research Publishing Inc. This work is licensed under the Creative Commons Attribution International License (CC BY 4.0).

http://creativecommons.org/licenses/by/4.0/

\begin{abstract}
The paper tried to entangle the current puzzle on the implementation of the balanced scorecard, especially within a health-service provider. By positing two folding questions which address the possible antecedents for the successful balanced scorecard and how to perform each antecedent to deal with the current issue, the study begins with comprehensive literature reviews among more than 58 manuscripts from respective journals. Having performed the analysis in an objective manner, the study succeeded in identifying five possible antecedents as crucial elements to BSC: (1) vision and mission, (2) organizational fitness, (3) organizational capabilities, (4) technological support and (5) organizational commitment. Furthermore, in maintaining the objectivity, the study also analyzed major challenges faced in the health-service industry. Our findings portrayed three major challenges: (1) due to objectivity of the measurement process, (2) organizational capability's consideration and (3) special organizational characteristics. Therefore, we enclosed the paper with proposing a firm model which can be used as future guidance for the health-service provider to implement the balanced scorecard, thus preparing the next stage for future research directions.
\end{abstract}

\section{Keywords}

The Balanced Scorecard, Health-Care Industry, Organizational Performance

\section{Introduction}

As popular performance measurement tools, the balanced scorecard (BSC) has been widely used for more than two decades. Manufactures as well as service 
sectors have benefited from BSC. Several former scholars signaled the use of balanced scorecard as a vital tool in formulating strategy [1] [2] [3]. They concluded that BSC was not only providing clear guidance but also addressing linkage to organizational performance.

Though the concept is still under development, previous research had justified the use of the balanced scorecard not only from the industrial-level perspective, but also from the managerial functions such as supply chain [4] [5], marketing point of view [6] [7], financial perspective [8] [9] as well as information systems [10]. As a result, many scholars started to question the accuracy of this measurement. Some of them even doubted the objectivity of the measurement for each perspective [11] [12] [13] [14]. This issue had become unended debatable topics for decades. Furthermore, this phenomenon also happened to the healthcare fields of studies.

In general, the research on the use of the balanced scorecard in this industry can be divided into two major categories: (1) those who affirm the proper use of BSC and (2) those who conclude that the major revisions are needed before it can be fully adapted to the health-care sectors. By posing the importance of objectivity in the analysis, this paper tried to provide comprehensive literature reviews in order to identify antecedents for the successful implementation of the balanced scorecard while using those antecedents to disentangle the failure of adopting the concept into the health-care industry.

The rest of the paper will be organized as follows: the next section will provide the literature review related to how the balanced scorecard was implemented on the health care sector. Section three will provide research methods. Section four describes all findings and provides a discussion to identify future directions. Last, section five states the conclusions.

\section{Literature Review}

\subsection{Revising the Concept}

The balanced scorecard was first introduced by Robert Kaplan and David Norton in the late 90's as a performance measurement. The model consists of four perspectives which later have been extended by including a vision strategy and subsets of strategic objectives initiatives. Referring to the original model, the four perspectives are financial perspectives, internal business processes, organizational capacity and customer perspectives. Meanwhile, for some specific applications among the service industry, they use different words to clarify the meaning. The first perspective is stewardship which represents the financial perspective, followed by efficiency to represent the internal business processes, knowledge and innovations as appointed the organizational capacity and the final stakeholder satisfaction as customer perspective [15].

For the further use, the author suggested to develop metrics, collecting some evidences as raw data and trying to analyze the date among each perspective. For example, to analyze the organizational capability perspective, we need to collect 
data and information related to (1) employee training programs for both target and realization in details, (2) internal and external knowledge circulation related to activities and events, (3) any achievement to show the relevance of the previous training and the individual outcome. By categorizing all of these by metrics, managers may have guidance to measure the effectivity of each training activity provided in fulfilling the ultimate goals.

Although it seems simple, in fact, several researches have already signaled some problems starting from data collection phase [16] [17] [18] up to the issue of objectivity [11] [12] [19] [20]. These series of researches highlighted the common practice is that managers only use the desirable facts or evidence that benefited their performance. Though it has nothing to do with the original concept, but behavioral considerations have made the balanced scorecard seen as subjective performance-measurement tools. If this also counted for the health service sector, it may have a direct impact on the stakeholders.

Having posed the previous symptom, our literature review will try to provide comprehensive analyses on how a company succeeds in implementing the concept while others don't. Moreover, considering that the final outcome of this paper must fully address the implementation of the health-service sector, then our analysis will be performed on a sequential basis. First, we will examine how manufactures and service companies achieve their success level and why they failed. On the second part, the analysis using the health service organization will be employed to formulate the insight for future directions.

\subsection{Possible Crucial Factors}

Former studies with the positive conclusion regarding the implementation of balanced scorecard can be found in several industries ranging from textile [21] [22] [23], logistic [1] [5], the research industry [24], the information technology industry [25], the educational sector [26], the government sector [27] [28], the tourism industry [29] and even small-medium enterprises [30]. Most of them found that the crucial factors had been found in the ability of a company to apply the stated vision and mission with a strategic action. This finding has led to the extension of the balanced scorecard. In early 2000, Kaplan and Norton tried to promote their revision towards the original model.

Linking vision and mission into daily tactics was believed as a signal to new paradigm in strategic management. At this stage, vision is no longer defined as a mere dream, and mission is no longer understood as derivation product of vision. Furthermore, vision must be defined as targeted dreams for certain periods [31]. Meanwhile, mission should be seen as the answer of the basic question "what business we are in". Mission is more to the definition of any kind of service that the organization might provide to the stakeholders [32]. The new thought was further used as a central concept in the modified balanced scorecard.

The second crucial factors can be found on how the company tried to implement the concept into a strategic action. At this point, the balanced scorecard is 
no longer used as mere performance measurement tools, but more as strategic planning tools. On the annual planning stage, before proposing the budget, management can use the four perspectives of the balanced scorecard to provide insights for further improvements [2] [33] [34]. Right after the new insight was found, the next steps would be applying the concept into the strategic objectives, followed by a strategic map, performance measures and targets, down to strategic initiatives.

Moreover, using the previous steps to form a daily strategy requires detailed insights for some prospectus environmental changing. This is the point where almost failure in using the balanced scorecard begins. Some scholars identified that the failure was caused by the absence of external analysis [35] [36] [37], but some concluded that it has something to do with the internal capability [14] [38]. Upon its doubtful essence, in fact, there's still no common concession on how an organization must deal with these circumstances. Uniquely, the concepts still recall as the ideal performance measurement tools for the $21^{\text {st }}$ century.

\section{Research Method}

This study used the qualitative explanatory approach in finding the firm direction for future research. This approach has been proven effective in providing systematic mechanism to the scholars in portraying the current phenomenon. We begin the mechanism by exploring all related research on the balanced scorecard from early 1990's to 2015. Each paper will be analyzed through several categories (1) the unit of analysis, (2) research methods, and (3) the final conclusion. At this point, we try to ignore the role of industrial effects because we think that taking the issue into analysis will eliminate any possible facts to have a clear direction for future research.

The further step would be identifying the key success factor and key challenge in implementing the concepts. Finally, we will use the previous finding to provide new insights and clear directions for future research.

\section{Analysis and Discussion}

Due to its plethora of studies, using Google scholars as database, we found 138,000 academic-related works regarding the topics. From those numbers, 28\% of which were books, $32 \%$ of which were articles and the rests are published manuscripts from more than 58 countries which represent the West and East insights related to the balanced scorecard. After considering the relevance of the findings, the number of citations and images of the journal, we decided to choose 63 manuscripts for further analysis, including those who published by: Long Range Planning, Benchmarking: An International Journal, Management Decision, Accounting and Finance Research, Journal of Education for Business, International Journal of Operations and Production Management, Computers and Industrial Engineering, Journal of Business Logistic, Journal of Health Care Management, European Accounting Review and Environmental Quality Man- 
agement.

Uniquely, from 63 manuscripts, 22 of them explained the challenging stories regarding the concept while the rest of them were showing positive evidences. The next section will discuss the findings from each category.

\subsection{Learning from Successful Stories}

In this section, we will identify factors which lead the organization to succeed in implementing balanced scorecard. There are five potential factors to be antecedents: 1) vision and mission, 2) organizational fitness, (3) organizational capabilities, 4) technological support and 5) organizational commitment. Details of each antecedent can be seen on Table 1 .

Our findings first give attributes to the vital role of vision and mission in implementing the balanced scorecard. Series of researches done by [26] [30] [39] [40] [41] [42] [43], highlighted the balanced scorecard as measurement tools which tried to develop firm linkage between vision and mission down to strategic implementation. And on reverse flows, every outcome will be measured to address the level of fitness to the previous vision and mission. Moreover, for those who share blurred pathways, through the matrices, the manager will easily identify which point the broken path should be revised in. On the contrary, for

Table 1. Possible key success factors for BSC.

\begin{tabular}{|c|c|c|c|}
\hline No. & KSF & Definition & References \\
\hline 1 & $\begin{array}{l}\text { Vision and } \\
\text { mission }\end{array}$ & $\begin{array}{l}\text { Vision refers to companies' targeted } \\
\text { dreams. It relates to answer the question } \\
\text { what do you want to be in some specific } \\
\text { future's time-frame }\end{array}$ & $\begin{array}{l}\text { Beard, 2009; Wongrassamee and } \\
\text { Simmons, 2003; Niven, 2002; Inamdar } \\
\text { and Kaplan, 2002; Kaplan and } \\
\text { Norton, 1998, 1996; Chow et al., } 1997\end{array}$ \\
\hline 2 & $\begin{array}{l}\text { Organizational } \\
\text { fitness }\end{array}$ & $\begin{array}{l}\text { Referring to how fit organizational } \\
\text { infrastructure can meet the requirement } \\
\text { of the measurement. Complexity as well } \\
\text { as simplicity can caused problems upon } \\
\text { measurement level }\end{array}$ & $\begin{array}{l}\text { Beard, 2009; Braam and Nijsen, 2004; } \\
\text { Richardson, 2004; Norrie and Walker, } \\
\text { 2004; Inamdar and Kaplan, 2002; } \\
\text { Kaplan and Norton, 2001; Silk, 1998; } \\
\text { Epstein and Manzoni, } 1997\end{array}$ \\
\hline 3 & $\begin{array}{l}\text { Organizational } \\
\text { capabilities }\end{array}$ & $\begin{array}{l}\text { Referring to how well people within } \\
\text { lorganization can deployed the } \\
\text { measurement to provide new insight for } \\
\text { future improvement }\end{array}$ & $\begin{array}{l}\text { Basuony, 2014; Eliat et al., 2008; } \\
\text { Braam and Nijsen, 2004; Voelker et } \\
\text { al., 2001; Brewer and Speh, 2000; } \\
\text { Hoque and James, 2000; Kaplan and } \\
\text { Norton, } 1996\end{array}$ \\
\hline 4 & $\begin{array}{c}\text { Technological } \\
\text { support }\end{array}$ & $\begin{array}{l}\text { Referring to the role of technology to } \\
\text { provide positive supports to the } \\
\text { limplementation of BSC. Addressing the } \\
\text { help of technology factors will be } \\
\text { beneficial since the evaluation can } \\
\text { be done in shorter periods }\end{array}$ & $\begin{array}{l}\text { Chand et al., 2005; Braam and Nijsen, } \\
\text { 2004; Norrie and Walker, 2004; Millis } \\
\text { and Mercken, 2004; Figge et al., 2002; } \\
\text { Kasurrinen, 2002; Niven, 2002; } \\
\text { Martinsons, et al., 1999; Silk, 1998; } \\
\text { Epstein and Manzoni, } 1997\end{array}$ \\
\hline 5 & $\begin{array}{l}\text { Organizational } \\
\text { commitment }\end{array}$ & $\begin{array}{l}\text { Referring to how strong the } \\
\text { lcommitment will be given by all } \\
\text { members towards the } \\
\text { implementation of BSC }\end{array}$ & $\begin{array}{l}\text { Atkinson, 2006; Davis and Albright, } \\
\text { 2004; Norrie and Walker, 2004; Kim } \\
\text { et al., 2002; Ittner et al., 2002; } \\
\text { Inamdar and Kaplan, 2002; Ahn, } \\
\text { 2001; Kaplan and Norton, } 1998\end{array}$ \\
\hline
\end{tabular}

Source: author compilations. 
those who show clear pathways, then it would be easier for the company to address the accuracy of each decision for their contribution on vision and mission, thus prolonging the sustainability of the organization.

The second crucial elements can be found on the organizational fitness to the requirement of the balanced scorecard (Table 2). Though it is not clearly stated, implementing the balanced scorecard requires a specific organizational structure [1] [26] [41] [44] [45] [46] [47] [48]. For example, use BSC as measurement tools, an organization must be well-operated through their planning up to control mechanism. Effectivity of the internal audit process, risk management and corporate planning units somewhat become pivotal factors. Once the function is not working properly, then the control mechanism won't be able to provide early warnings regarding the imbalanced condition.

Most of organization which failed in using balanced scorecard as performance measurement tools found to experience low fitness. But it doesn't mean that a simple-form organization always fails to implement the balanced scorecard. As long as each function can be addressed effectively, then the card can be performed positively.

Another crucial element can be found in organizational capabilities. Research done by [1] [5] [24] [38] [43] [49] [50], highlighted the importance of the ability of all employees in addressing the issues on the balanced scorecard. The BSC is actually more than measurement tools. It also benefited the company by giving a clear insight when they plan the overall action. Unfortunately, some organizations failed in developing the common understanding of this concept. Lack of knowledge regarding how this mechanism should be performed will give a bad impact on the overall process.

At the advanced steps of implementing the balanced scorecard, the strong support from the technological dimension is required. Today, a lot of programs have been succeeded in addressing this issue. Having considered a user's variance capability, to date, massive developments of BSC software aimed to provide comprehensive information on the simple CEO-interface platform. Thus,

Table 2. Possible constraints for BSC.

\begin{tabular}{|c|c|c|}
\hline No. & Indicators & References \\
\hline 1 & $\begin{array}{l}\text { Weak and unmeasurable } \\
\text { vision and mission }\end{array}$ & $\begin{array}{l}\text { Beard, 2009; Wongrassamee and Simmons, 2003; Niven, } \\
\qquad 2002\end{array}$ \\
\hline 2 & $\begin{array}{l}\text { Complex organizational } \\
\text { structure }\end{array}$ & Beard, 2009; Braam and Nijsen, 2004; Richardson, 2004 \\
\hline 3 & $\begin{array}{l}\text { Weak organizational } \\
\text { capabilities }\end{array}$ & $\begin{array}{l}\text { Basuony, 2014; Eliat et al., 2008; Braam and } \\
\text { Nijsen, 2004; Voelker et al., } 2001\end{array}$ \\
\hline 4 & Low technological support & $\begin{array}{l}\text { Chand et al., 2005; Braam and Nijsen, 2004; Norrie and } \\
\text { Walker, 2004; Millis and Mercken, 2004; Figge et al., } 2002\end{array}$ \\
\hline 5 & Weak commitment & $\begin{array}{l}\text { Atkinson, 2006; Davis and Albright, 2004; Norrie and } \\
\text { Walker, 2004; Kim et al., } 2002\end{array}$ \\
\hline
\end{tabular}

Source: author compilations. 
the imbalance performance can be detected on early stage. Known as CEOdesktop profile, on the timely basis, every decision maker is supported by realtime information provided to ensure that every strategy has been conducted towards the company's vision and mission.

Though the process is somewhat very ideal, some scholars also emphasized the importance of organizational commitment in the implementation stage [6] [8] [11] [19] [45]. Having proper knowledge about BSC in accordance with the great support from technological dimension is believed to provide powerful commitment to all members to perform the balanced scorecard well.

\subsection{Experiencing the True Challenges}

As performance measurement tools, the concept of the balanced scorecard must be compared with some other well-known mechanisms, ranging from: (1) EFQM excellence model [39], (2) system framework [51], (3) evidence based practice [52] and (4) statistical quality control [53]. Due to lack of information which analyzes the comparison for each tool, scholars believed that every measurement has its own strength and weakness, including the level of acceptance for practical fields.

Due to the plethora of studies, some scholars begin to identify the true challenges in implementing the balanced scorecard. First, it is related to the objectivity of the measurement [17] [30] [37] [50]. As commonly understood, up to the evaluation phase, the balanced scorecard requires some important supporting documents such as organizational foundation values, including vision and mission, organizational long-range and short-range objectives, strategic plans, execution plans, annual budgets and performance control mechanisms. To Malina and Selto [17], Hoque and James [50] and Chow et al. [30], managers have the opportunity and power to define which document should be used for further analysis, thus raising the issue of subjectivity. Recalling the problem of information asymmetric, these challenges are remained unsolved [54].

The second challenges can be found on the level of awareness in implementing the concept. As mentioned in the previous section, one of the critical issues in the balanced scorecard is how each member within a company can share the same common ground of understanding. Norreklit [36] mentioned that even for the company which declared using the best way in implementing the balanced scorecard, the chance of imbalanced knowledge regarding the BSC concept can be found easily. This is why some scholars appointing organizational size as one of the considerations [14].

The third challenge can be found related to the organizational specification. In the service industry, such as the hospitals, putting the financial perspective can somehow turn the characteristics of non-profit organizations into the commercial sector [7] [14] [36] [55]. Therefore, repositioning among each perspective is needed with a view to making the concept clearer; otherwise, it will affect the whole philosophy of the organization. 


\subsection{New Insight for the Health Service Sector}

Having considered all current development and challenges regarding the implementation of the balanced scorecard, it is plausible to propose our insights as seen on Figure 1.

Begin with the understanding that the hospital is a non-profit organization which fully addresses the important role of the stakeholders while implementing the balanced scorecard at an early stage is required. This stage should be performed before the organization decides to adopt the new performance measurement tools. Moreover, several points should be well-performed, including clear and measurable vision and mission, organizational fitness, capabilities, commitment and technological support.

Aside from vision and mission, a hospital needs to consider redesigning their organizational structure due to the requirements from the BSC. Inserting the function of internal audit and risk management units is crucial to perform daily evaluation basis. Furthermore, before implementing the concept, an organization needs to address the true concept of the balanced scorecard to the entire members. This is important since they need to relate every daily activity to the achievement of the overall performance.

In order to improve the objectivity, a hospital also needs to address the support from technology. Preparing the needed technological infrastructure might assure the successful implementation of the BSC upon the practical basis. As point to that, having the previous elements working-well in the hospital, organizational commitment will automatically become higher. This is the foundation to use the BSC upon the true paradigm level.

For the state of the art, the balanced scorecard must serve as the strategic planning measurement. This is true, for the scorecard shares the ability to build strong linkages between vision and mission with all four perspectives. As a result, we can have strategic initiatives as the ultimate outcome for daily operational guidance. In terms of the business policy, it will be defined as the most adequate way to create an organizational annual budget. Furthermore, some scholars acknowledged this steps as the subsets of performing activities based on budgeting [56] [57].

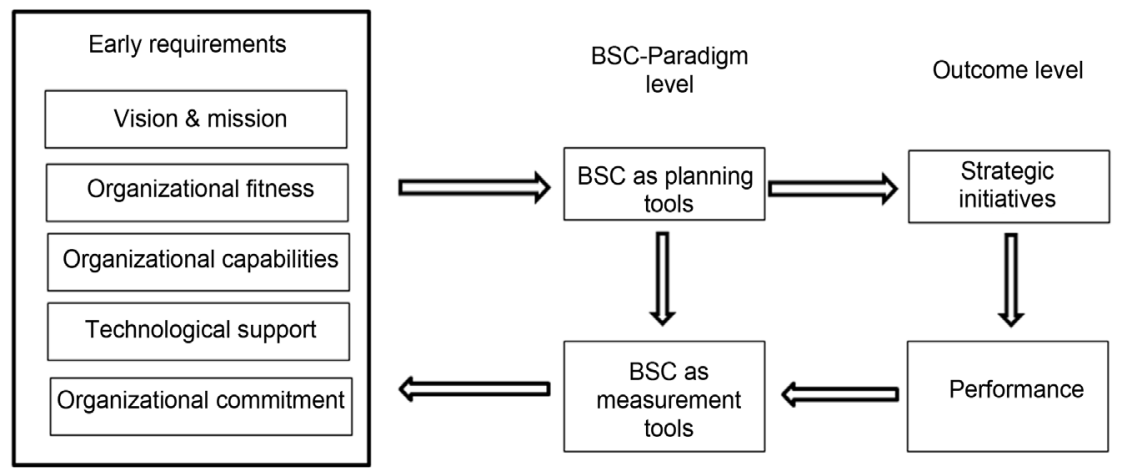

Figure 1. General framework. 
Once the annual strategic plan has been implemented, then our proposed model shows that the management team can use a balanced scorecard as performance measurement tools every certain period. By introducing the support from the technological sector, every potential issue can be detected at the early stage; therefore, the management has the chance to perform their corrective decision. At this point, BSC can also share the information which is required to update the four fundamental elements starting from vision and mission, organizational fitness, capabilities and commitments. Having performed the proposed mechanism well, one might guarantee that organizational platform has been operated effectively. Moreover, a hospital can achieve its ultimate goals, satisfying the internal as well as external stakeholders at the same time.

\section{Conclusions}

Starting with doubtful thoughts related to the ambiguous implementation of the balanced scorecard, this study poses two folding questions: 1) what are the antecedents for the successful implementation of the balanced scorecard and 2) how to deploy those antecedents disentangled the challenges of adopting the concept into health-care industry. Our comprehensive literature reviews have found five key elements: 1) vision and mission, 2) organizational fitness, 3) organizational capabilities, 4) technological support and 5) organizational commitments.

We defined those five elements as the key factors since it has direct effects to solve the current challenge. Most health care sectors are still struggling to adopt the balanced scorecard, especially in terms of: 1) objectivity, 2) low organizational capability and 3) due to organizational specification. Therefore, we enclosed the paper with the proposed model to become the future benchmark to those who want to implement the concept properly.

The study shared limitations which limit to propose the model. Therefore, a future study needs to apply the model into testable propositions and has it measured on the level of the empirical test. Having this step, we believed that the proposed model can contribute to the current knowledge especially in using the most adequate performance measurement tools due to the special characteristic of the organization.

\section{References}

[1] Braam, G.J.M. and Nijssen, E.J. (2004) Performance Effects of Using the Balanced Scorecard: A Note on the Dutch Experience. Long Range Planning, 37, 335-349. https://doi.org/10.1016/j.lrp.2004.04.007

[2] Figge, F., Hahn, T. and Schaltegger, S. (2002) The Sustainability Balanced Scorecard Linking Sustainability Management to Business Strategy. Business Strategy and the Environment, 11, 269-284. https://doi.org/10.1002/bse.339

[3] Kaplan, R.S. and Norton, D.P. (2001) Transforming the Balanced Scorecard from Performance Measurement to Strategic Management. Accounting Horizons, 15, 147-160. https://doi.org/10.2308/acch.2001.15.2.147

[4] Bhagwat, R. and Sharma, M.K. (2007) Performance Measurement of Supply Chain 
Management: A Balanced Scorecard Approach. Computers \& Industrial Engineering, 53, 43-62. https://doi.org/10.1016/j.cie.2007.04.001

[5] Brewer, P.C. and Speh, T.W. (2000) Using the Balanced Scorecard to Measure Supply Chain Performance. Journal of Business Logistic, 21, 75-93.

[6] Kim, J., Suh, E. and Hwang, H. (2003) A Model for Evaluating the Effectiveness of CRM Using the Balanced Scorecard. Journal of Interactive Marketing, 17, 5-19. https://doi.org/10.1002/dir.10051

[7] Hoque, Z. (2014) 20 Years of Studies on the Balanced Scorecard: Trends, Accomplishments, Gaps and Opportunities for Future Research. The British Accounting Review, 46, 33-59. https://doi.org/10.1016/j.bar.2013.10.003

[8] Davis, S. and Albright, T. (2004) An Investigation of the Effect of Balanced Scorecard Implementation on Financial Performance. Management Accounting Research, 15, 135-153. https://doi.org/10.1016/j.mar.2003.11.001

[9] Libby, T., Salterio, S.E. and Webb, A. (2004) The Balanced Scorecard: The Effects of Assurance and Process Accountability on Managerial Judgment. The Accounting Review, 79, 1075-1094. https://doi.org/10.2308/accr.2004.79.4.1075

[10] Martinsons, M., Davidson, R. and Tse, D. (1999) The Balanced Scorecard: A Foundation for the Strategic Management of Information System. Decision Support System, 25, 71-88. https://doi.org/10.1016/S0167-9236(98)00086-4

[11] Ittner, C.D., Larcker, D.F. and Meyer, M.W. (2003) Subjectivity and the Weighting of Performance Measures: Evidence from a Balanced Scorecard. The Accounting Review, 78, 725-758. https://doi.org/10.2308/accr.2003.78.3.725

[12] Lipe, M.G. and Salterio, S.E. (2000) The Balanced Scorecard: Judgmental Effects of Common and Unique Performance Measures. The Accounting Review, 75, 283-298. https://doi.org/10.2308/accr.2000.75.3.283

[13] Norreklit, H. (2000) The Balance on the Balanced Scorecard: A Critical Analysis of Some of Its Assumptions. Management Accounting Research, 11, 65-88. https://doi.org/10.1006/mare.1999.0121

[14] Mooraj, S., Oyon, D. and Hostettler, D. (1999) The Balanced Scorecard: A Necessary Good or an Unnecessary Evil? European Management Journal, 17, 481-491.

[15] Kaplan, R.S. and Norton, D.P. (1996) Strategic Learning \& the Balanced Scorecard. Strategy \& Leadership, 24, 18-24. https://doi.org/10.1108/eb054566

[16] Fernandez, K.J., Raja, V. and Whalley, A. (2006) Lessons from Implementing the Balanced Scorecard in a Small and Medium Size Manufacturing Organization. Technovation, 26, 623-634.

[17] Malina, M.A. and Selto, F.H. (2001) Communicating and Controlling Strategy: An Empirical Study of the Effectiveness of the Balanced Scorecard. Journal of Management Accounting Research, 13, 47-90. https://doi.org/10.2308/jmar.2001.13.1.47

[18] Bourne, M., Mills, J., Wilcox, M. and Neely, A. (2000) Designing, Implementing and Updating Performance Measurement Systems. International Journal of Operations \& Production Management, 20, 754-771. https://doi.org/10.1108/01443570010330739

[19] Atkinson, H. (2006) Strategy Implementation: A Role for the Balanced Scorecard. Management Decision, 44, 1441-1460. https://doi.org/10.1108/00251740610715740

[20] Ahn, H. (2001) Applying the Balanced Scorecard Concept: An Experience Report. Long Range Planning, 34, 441-461.

[21] Cebeci, U. (2009) Fuzzy AHP-Based Decision Support System for Selecting ERP Systems in Textile Industry by Using Balanced Scorecard. Expert System with Ap- 
plications, 36, 8900-8909.

[22] Chand, D., Hachey, G., Hunton, J., Owhoso, V. and Vasudevan, S. (2005) A Balanced Scorecard Based Framework for Assessing the Strategic Impacts of ERP Systems. Computer in Industry, 56, 558-572.

[23] Perry, M., Sohal, A.S. and Rumpf, P. (1999) Quick Response Supply Chain Alliances in the Australian Textiles, Clothing and Footwear Industry. International Journal of Production Economics, 62, 119-132.

[24] Eliat, H., Golany, B. and Shtub, A. (2008) R \& D Project Evaluation: AN Integrated DEA and Balanced Scorecard Approach. Omega, 36, 895-912.

[25] Papalexandris, A., Ioannou, G. and Prastacos, G.P. (2004) Implementing the Balanced Scorecard in Greece: A Software Firm's Experience. Long Range Planning, 37, 351-366.

[26] Beard, D.F. (2009) Successful Applications of the Balanced Scorecard in Higher Education. Journal of Education for Business, 84, 275-282. https://doi.org/10.3200/JOEB.84.5.275-282

[27] McAdam, R. and Walker, T. (2003) An Inquiry into Balanced Scorecards within Best Value Implementation in UK Local Government. Public Administration, 81, 873-892. https://doi.org/10.1111/j.0033-3298.2003.00375.x

[28] Shih-Jen, K.H. and Yee-Ching, L.C. (2002) Performance Measurement and the Implementation of Balanced Scorecards in Municipal Governments. The Journal of Government Financial Management, 51, 8-19.

[29] Denton, G.A. and White, B. (2000) Implementing a Balanced Scorecard Approach to Managing Hotel Operations the Case of White Lodging Services. Cornell Hospitality Quarterly, 41, 94-107. https://doi.org/10.1177/001088040004100127

[30] Chow, C.W., Haddad, K.M. and Williamson, J.E. (1997) Applying the Balanced Scorecard to Small Companies. Management Accounting, 79, 21-27.

[31] Papulova, Z. (2014) The Significance of Vision and Mission Development for Enterprises in Slovak Republic. Journal of Economics, Business and Management, 2, 12 17. https://doi.org/10.7763/JOEBM.2014.V2.90

[32] Mourkogiannis, N. (2006) Purpose: The Starting Point of Great Companies. Palgrave Macmillan, New York.

[33] De Geuser, F., Mooraj, S. and Oyon, D. (2009) Does the Balanced Scorecard Add Value? Empirical Evidence on Its Effect on Performance. European Accounting Review, 18, 93-122. https://doi.org/10.1080/09638180802481698

[34] Veen-Dirks, P. and Wijn, M. (2002) Strategic Control: Meshing Critical Success Factors with the Balanced Scorecard. Long Range Planning, 35, 407-427.

[35] Anderson, K. and McAdam, R. (2004) A Critique of Benchmarking and Performance Measurement: Lead of Lag? Benchmarking: An International Journal, 11, 465-483. https://doi.org/10.1108/14635770410557708

[36] Norreklit, H. (2003) The Balanced Scorecard: What Is the Score? A Rhetorical Analysis of the Balanced Scorecard. Accounting, Organizations and Society, 28, 591 619.

[37] Storey, A. (2002) Performance Management in Schools: Could the Balanced Scorecard Help? School Leadership \& Management, 22, 321-338. https://doi.org/10.1080/1363243022000020435

[38] Basuony, M.A.K. (2014) The Balanced Scorecard in Large Firms and SMEs: A Critique of the Nature, Value and Application. Accounting and Finance Research, 3, 145-167. https://doi.org/10.5430/afr.v3n2p14 
[39] Wongrassamee, S. and Simmons, J.E.L. (2003) Performance Measurement Tools: The Balanced Scorecard and the EFQM Excellence Model. Measuring Business EXcellence, 7, 14-29. https://doi.org/10.1108/13683040310466690

[40] Niven, P.R. (2002) Balanced Scorecard Step by Step Maximizing Performance and Maintaining Results. John Wiley \& Sons, New York.

[41] Inamdar, N. and Kaplan, R.S. (2002) Applying the Balanced Scorecard in Healthcare Provider Organizations/Practitioner's Response. Journal of Healthcare Management, 47, 179-195.

[42] Kaplan, R.S. and Norton, D.P. (1998) Putting the Balanced Scorecard to Work. In: Siesfeld, T., Cefola, J. and Neef, D., Eds., The Economic Impact of Knowledge, Butterworth Heinemann, Boston.

[43] Kaplan, R.S. and Norton, D.P. (1996) Using the Balanced Scorecard as a Strategic Management System. Harvard Business Review, 76-81.

[44] Richardson, S. (2004) The Key Elements of Balanced Scorecard Success. Ivy Business Journal, 24, 7-11.

[45] Norrie, J. and Walker, D. (2004) A Balanced Scorecard Approach to Project Management Leadership. Project Management Journal, 35, 47-56.

[46] Kaplan, R.S. and Norton, D.P. (2001) The Strategy-Focused Organization: How Balanced Scorecard Companies Thrive in the New Business Environment. In: Duarte, H.J., Ed., Fundamentals of Knowledge II, Atlantic International University, European Union. https://doi.org/10.1108/sl.2001.26129cab.002

[47] Silk, S. (1998) Automating the Balanced Scorecard. Strategic Finance, 79, 38-42.

[48] Epstein, M.J. and Wisner, P.S. (2001) Using a Balanced Scorecard to Implement Sustainability. Environmental Quality Management, 11, 1-10.

https://doi.org/10.1002/tqem.1300

[49] Voelker, K.E., Rakich, J.S. and French, G.R. (2001) The Balanced Scorecard in Healthcare Organizations: A Performance Measurement and Strategic Planning Methodology. Hospital Topics, 79, 13-24.

https://doi.org/10.1080/00185860109597908

[50] Hoque, Z. and James, W. (2000) Linking Balanced Scorecard Measures to Size and Market Factors: Impact on Organizational Performance. Journal of Management Accounting Research, 12, 1-17. https://doi.org/10.2308/jmar.2000.12.1.1

[51] Hervani, A., Helms, M.M. and Sarkis, J. (2005) Performance Measurement for Green Supply Chain Management. Benchmarking. An International Journal, 12, 330-353. https://doi.org/10.1108/14635770510609015

[52] French, B., Thomas, L.H., Baker, P., Burton, C.R., Pennington, L. and Roddam, H. (2009) What Can Management Theories Offer Evidence-Based Practice? A Comparative Analysis of Measurement Tools for Organizational Context. Implementation Science, 28, 235-256.

[53] Flynn, B.B., Schroeder, R.G. and Sakakibara, S. (1994) A Framework for Quality Management Research and an Associated Measurement Instrument. Journal of $O p$ erations Management, 11, 339-366.

[54] Zimmerman, J.L. and Zadeh, M.Y. (2011) Accounting for Decision Making and Control. Issues in Accounting Education, 26, 257-259. https://doi.org/10.2308/iace.2011.26.1.258

[55] Zelman, W.N., Pink, G.H. and Mathias, C.B. (2003) Use of the Balanced Scorecard in Health Care. Journal of Health Care Finance, 29, 1-16.

[56] Hansen, S.C. (2011) A Theoretical Analysis of the Impact of Adopting Rolling 
Budgets, Activity-Based Budgeting and beyond Budgeting. European Accounting Review, 20, 289-319. https://doi.org/10.1080/09638180.2010.496260

[57] Cooper, R. and Slagmulder, R. (2000) Activity-Based Budgeting. Strategic Finance, 82, 85-86. 